\title{
A GENERIC STRATEGIC SUPPLIER SELECTION MODEL IN INFORMATION AND COMMUNICATION TECHNOLOGIES
}

Ali Emre KARAÖZ1

Kemal TEKIN ${ }^{2}$

Göknur Arzu AKYÜZ3

\author{
Received Date (Başvuru Tarihi): 18/06/2019 \\ Accepted Date (Kabul Tarihi): 02/09/2019 \\ Published Date (Yayın Tarihi): 25/09/2019
}

\section{ABSTRACT}

The topic of supplier rating and selection has gained strategic importance in supply chain management, and supplier selection process is considered as a multi-criteria decision-making issue in the literature. This study focuses on the strategic supplier selection for the suppliers providing goods and services in information and communication technologies (ICT) sector. A comparative analysis is made in the case company. During the analysis, a mapping of the criteria used in the case company onto the criteria existing in the literature is made, and the comparative study is performed with two different weight sets. It is revealed that the results from the proposed integrated TOPSIS - [ANP-TOPSIS] approach resulted in more discriminatory results. Based on the comparative approach used and the need for a decision support system, a generic model for supplier selection and a conceptual design of a decision support system in connection with this generic model are suggested.

Keywords: Strategic Supplier Selection, Supplier Rating, ANP, TOPSIS, Multi-Criteria Models

JEL Codes: C02, C38, C67, L20, M11, O21

\section{BİLGİ VE İLETIŞIMM TEKNOLOJILLERINDE GENEL BİR STRATEJİK TEDARİKÇI SEÇIM MODELI}

$\ddot{O} Z$

Tedarikçi derecelendirme ve seçim konusu, tedarik zinciri yönetiminde stratejik önem kazanmıştır ve tedarikçi seçim süreci, literatürde çok kriterli karar verme konusu olarak görülmektedir. Bu çalışma, bilgi ve iletişim teknolojileri (BIT) sektöründe mal ve hizmet sağlayan tedarikçiler için stratejik tedarikçi seçimine odaklanmaktadır. Örnek şirkette karşılaştırmalı bir analiz yapılmıştır. Analiz sırasında, şirkette kullanılan kriterlerin literatürde var olan kriterlere göre eşleştirilmesi yapılmış ve karşılaştırmalı çalışma iki farklı ă̆ırlık seti ile gerçekleştirilmiştir. Önerilen entegre TOPSIS - [ANP-TOPSIS] yaklaşımından elde edilen sonuçların daha ayırımcı sonuçlarla sonuçlandı̆̆ ortaya çıkmıştır. Kullanılan karşılaştırmalı yaklaşıma ve karar destek sistemine olan gereksinime dayanarak, tedarikçi seçimi için genelleştirilmiş bir model ve bu genelleştirilmiş model ile bağlantılı olarak bir karar destek sisteminin kavramsal tasarımı önerilmektedir.

Anahtar Kelimeler: Stratejik Tedarikçi Seçimi, Tedarikçi Derecelendirme, ANP, TOPSIS, Çok Kriterli Modeller

JEL Kodlart: C02, C38, C67, L20, M11, O21

\footnotetext{
${ }^{1}$ Dr., University of Turkish Aeronautical Association Graduate, emre.karaoz@ hotmail.com

${ }^{2}$ Dr., Freelance Researcher, kemtek2003@yahoo.com

${ }^{3}$ Asst. Prof. Dr., University of Turkish Aeronautical Association, arzu.akyuz@ gmail.com
}

https://orcid.org/0000-0002-3809-1599 https://orcid.org/0000-0003-0270-4899 https://orcid.org/0000-0003-2024-5884 


\section{INTRODUCTION}

Information and communication (ICT) technology, an integral part of today's business and social life, is a sector which is experiencing a continuous global growth (Fazlollahtabar et al., 2011; Ispat, 2014). This rapid growth is foreseen to continue (ITU, 2016), and Turkey is expected to grow faster than the global average (Ispat ,2017). Efficient and effective use of the ICT technologies act as a leverage in the development of the countries (TWB, 2016). Procurement activities in this sector are majorly project-based, suppliers assuming a strategic partner position working in full compliance with the company, and providing end-to-end solutions.

Strategic importance of effective supplier selection in creating a competitive advantage is well-supported (Hsu et al. 2006) literature. Depending on the company strategy, functional managers must identify their strategic priorities and the procurement strategy should be consistent with the competitive strategy (Chau and Chang, 2008). Strategic partnership with better performing suppliers should be integrated into the supply chain to improve the performance in various aspects including reducing costs by eliminating wastages, continuously improving quality to achieve zero defects, improving flexibility to meet end-customer needs, reducing lead time at different stages of the supply chain, and so on (Kumar, Vrat and Shankar, 2014). Hence, this strategic importance is especially true for the ICT sector which demands more strategic-level procurement solutions.

This study investigates strategic supplier selection topic in ICT sector based on a case company data and application. The topic is inherently a multi-criteria decision-making problem containing many conflicting objective and subjective criteria within the process (Carter et al., 2010, Arauju, Alencar and Viana, 2015; Ounnar and Pujo, 2005).

Within the scope of this study, first of all, a review is made for the multi-criteria decision making models and the criteria used in the literature, providing a detailed analysis of existent criteria sets, models and methods. The literature review strongly supports the frequent use as well as the practicality of ANP and TOPSIS, and the applicability of the combined use of these two methods in the ICT sector. Hence, afterwards, a comparative study is made based on multicriteria models, to analyse the behaviour of ANP, ANP-TOPSIS (Analytic Network Process Technique for Order Preference by Similarity to an Ideal Solution) and combined TOPSIS[ANP-TOPSIS] methods against the existing supplier selection methodology of the selected case company. 
Based on the results of this comparative study, a generic model for supplier selection and a conceptual design of a decision support system is suggested. As supported by Matopuolos et al. (2016), using empirical results in order to develop and to improve models provides advantages, and can lead to tools which can be used in practice by purchasing experts, consultants and policy-makers (Igarashi et al., 2013). Buyers prefer the buyer-determined auction over the price-based auction (Brosig-Koch and Heinrich ,2014), so it is important for a company to have its own tailored supplier selection system.

The contributions of the study are as folows:

- It provides a Turkish case study.

- Based on well-proven multi-criteria methods, the study offers a generalized comparative process and a flexible decision-support system for strategic decision making.

- Highlights the importance of collaboration, flexibility, environment and innovation concepts in the selection of a contemporary criteria set for supplier selection evaluations.

With these characteristics, the study is valuable from practitioner's perspective, not only for the ICT sector but also for the other sectors.

Section structure for the rest of the article is as follows: Section 2 presents the literature review and discusses the existing supplier selection models and selection criteria. Section 3 presents the general information about the selected case study company, and describes the supplier selection systematic used in the company. Section 4 describes the methodology used in the application. In section 5, mapping of the criteria used in the existing case application onto the criteria existing literature is performed to provide an applicable criteria set in ICT sector. Section 6 provides the comparative results of the alternative methods applied. Based on these results, Section 7 describes a generic supplier selection model which is applicable in other sectors or companies as well, and offers a conceptual design toward decision support. The last section contains conclusion and further research suggestions.

\section{LITERATURE REVIEW}

Since the ICT sector is highly technology-intensive and fast-changing, 39 resources published after year 2000 and containing at least one supplier selection application are included within the scope of the literature review. The articles are analysed in detail for the models and criteria used. The resource set contains items published in indexed journals mainly after 2009. Based on these resources, this section discusses the existing studies with respect to sectoral distribution, methods and criteria used. 


\subsection{Sectoral Evaluation}

When the resources are evaluated with respect to the sectors in which the applications are made, the highest number of applications is in electronic production sector, followed by automotive, hi-tech equipment manufacturing, and production sectors. Since the resource set contains recent studies performed in technology-intensive sectors, it can be easily argued that the resource set is highly relevant and closely related with ICT sector.

In terms of sectoral distribution, 26 out of 39 articles contain applications in technologyintensive sectors with the following distribution: 9 applications in electronic production (Amin and Zhang, 2012; Chan and Chan, 2004; Chen and Wu, 2013; Huang and Keskar, 2007; Kuo et al., 2010b; Lin et al., 2011; Narasimhan et. al, 2001; Pramanik et al., 2017; Wu et al., 2009), 8 applications in automotive sector (Aksoy and Öztürk, 2011; Golmohammadi, 2011; Huang and Hu, 2013; Kasirian and Yusuff, 2013; Sar1 and Timor, 2016; Shahroudi and Rouyde, 2012; Y1ld1z and Yayla, 2017; Zeydan et al., 2011), 3 applications in hi-tech equipment manufacturing (Kuo and Lin, 2012; Tseng and Lin, 2005; Wu and Weng, 2010), 2 articles in 3C (computers, communication and consumer electronics), (Chen et al., 2014; Chou ve Chang, 2008), 1 study in information (Amin ve Razmi, 2009), electronic market (Fazlollahtabar et al., 2011), 1 application in automotive lightening systems (Kuo et al. 2010a), and 1 hypothetical company (Chan, 2003). Since $70 \%$ of the resources are related with technology-intensive sectors, it can be easily argued that the resource set and the findings are highly relevant to ICT sector. It is also important to highlight that hypothetical studies are very few, and case study applications are dominant.

\subsection{Evaluation with Respect to Methods}

Usefulness of formal decision models throughout the entire supplier selection process under different purchasing circumstances is well-supported (Boer and Wegen, 2003). Regarding the applied methods, we witness the widespread use of various multi-criteria methods in both separate and combined manner.

Studies utilizing ANP in their combined methodologies can be mentioned as follows: ANP-Modified TOPSIS application by Shyur and Shih (2006); ANP and MIP (Mixed Integer Programming) combination in Wu et al. (2009); ANP-ANN (Artificial Neural Network) and DEA (Data Envelopment Analysis) in Kuo et al. (2010b); ANP-TOPSIS application in Lin et al. (2011) and Shahroudi and Rouydel (2012); ANP and DEA in Kuo and Lin (2012); TOPSISANP and "Preemptive Goal Programming" in Kasirian andYusuff (2013);ANP-ISM 
(Interpretive Structural Modeling) hybrid in Chen et al. (2014); Dematel, and ANP-Vikor combination in Ar et al. (2015); ANP-Taguchi and ANP-Promethee by Sarı and Timor (2016). It can be seen that in these combined models ANP is used especially for determining the criteria weights, since ANP utilizes the concept of dependence and feedback related with the criteria.

The use of AHP (Analitical Hierarchy Process) as part of a combined methodology is also well-supported in the literature (Chen and Wu, 2013; Fazlollahtabar et al., 2011; Supçiller and Çapraz, 2011; Alyanak and Armane, 2009; Tseng and Lin, 2005; Chan, 2003).

We witness the use of TOPSIS method as part of the combined methodology in Pramanik et al. (2017) and Jajidi et al. (2009). In the ideal solution mechanism of TOPSIS methodology, the alternative with the shortest or the longest geometric distances from the positive or the negative ideal solutions, respectively is selected.

The following items can be grouped as literature resources containing combined applications using methods different from the above-mentioned and frequently-seen methods: Pitchipoo et al. (2015); Huang and Hu (2013); Amin and Zhang (2012); Zeydan et al. (2011); Wu and Liu (2011); Kuo et al. (2010a).

The literature items containing a single method are determined as: Kumar et al. (2018), Y1ldız and Yayla (2017); Vahdani et al. (2015); Safa et al. (2014); Hruska et al. (2013); Aksoy and Öztürk (2011); Golmohammadi (2011); Liao et al. (2010); Wu and Weng (2010); Chou and Chang (2008); Huang and Keskar (2007); Chan and Chan (2004); Sarkis and Talluri (2002) and Narasimhan et. al (2001).

In 39 resources evaluated within the scope of the study, various supplier ranking and selection methods are observed, as depicted in Table 1. 
Table 1. Supplier Selection Methods Used in the Literature Items Selected

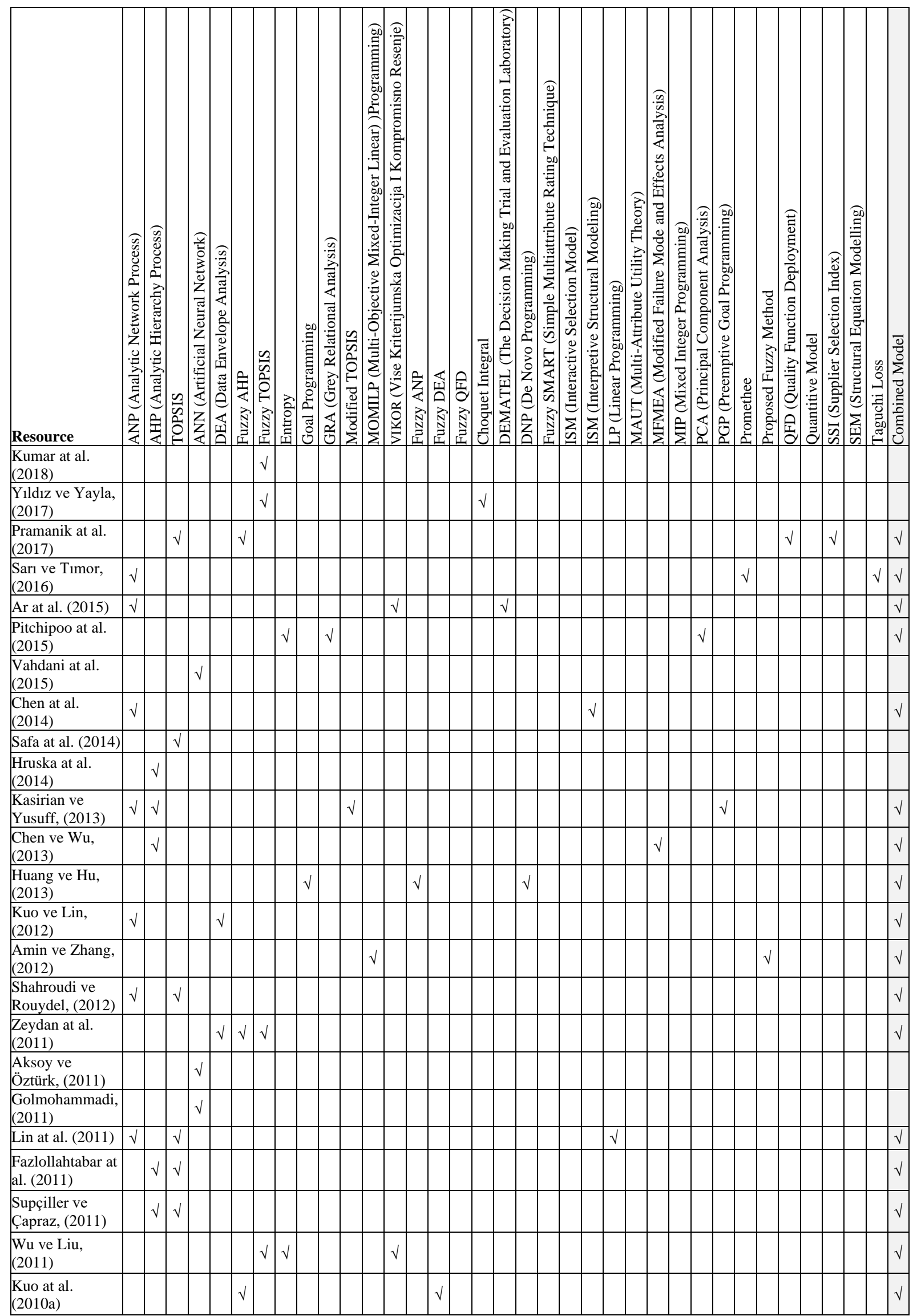




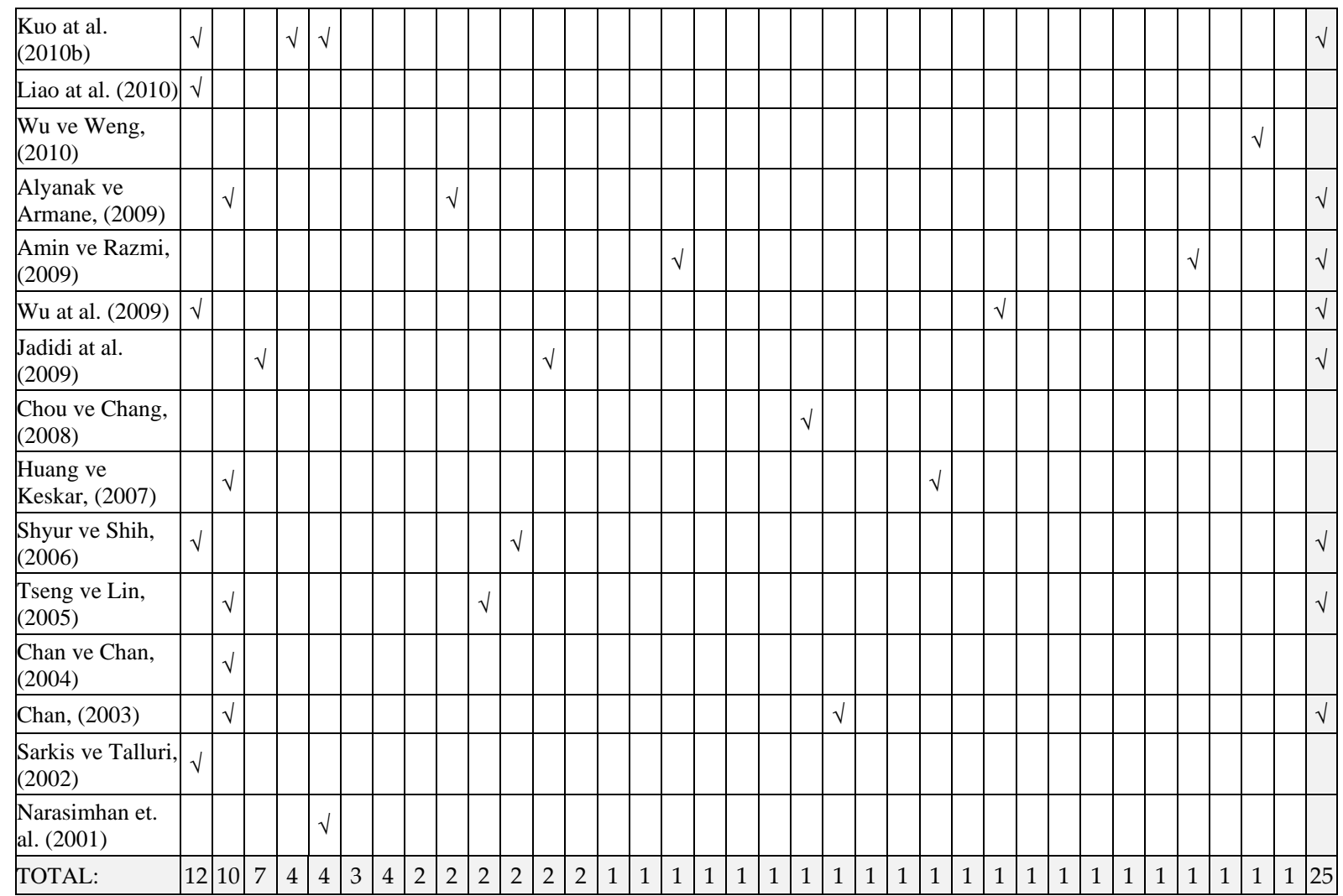

In the literature review, contrary to the dependence on the requirements of the pure methods, it is seen that it is possible to obtain more flexible and more distinctive decision making structures by using combined models.

Consequently, the literature review strongly supports the frequent use as well as the practicality of ANP and TOPSIS, and the applicability of the combined use of these two methods in the ICT sector. Hence, methodology given in section 3 is based on ANP and TOPSIS.

\subsection{Evaluation with Respect to Selection Criteria}

In terms of the selection criteria, it is widely accepted by both researchers and procurement people that focusing on the price and quality only is no longer sufficient. Choosing the right suppliers involves much more than scanning a series of price lists. Choices will depend on a wide range of issues (Arauju, Alencar and Viana, 2015), and suppliers are expected to be equipped with more capabilities (Madhukant, 2009; Erdal, 2011; Ar et al., 2015).

When focused on the resources in the review, 541 sub-criteria under 36 main criteria groups are observed. Ten most frequently used criteria appear as quality, cost/price, delivery, general supplier capabilities flexibility, service, environment, technology/innovation, production and management, respectively. Five more criteria following these initial 10 items 
are innovation, performance, technical performance, financial performance and implementation in their decreasing frequency of usage. It is also observed that in terms of the sub-criteria contained, these five criteria can be included in the first 10 criteria. According to this classification, it can be argued that first 15 criteria contain the sub-criteria to a significant extent.

It has been idenfied that these 10 criteria groups predominantly appear, and are supported in the following resources: Aksoy and Öztürk (2011); Alyanak and Armane (2015); Amin and Razmi (2009); Amin and Zhang (2012); Ar et al. (2015); Chan and Chan (2004); Chan (2003); Chen et al. (2014); Chen and Wu (2013); Chou and Chang (2008); Fazlollahtabar et al. (2011); Golmohammadi (2011); Hruska et al. (2013); Huang and Hu (2013); Huang and Keskar (2007); Jadidi et al. (2009); Kasirian and Yusuff (2013); Kuo et al. (2010a); Kuo et al. (2010b); Kuo and Lin (2012); Liao et al. (2010); Lin et al (2011); Narasimhan et. al (2001); Pitchipoo et al. (2015); Pramanik et al. (2017;) Safa at al. (2014); Sarı and Timor (2016); Sarkis and Talluri (2002); Shahroudi and Rouydel (2012); Shyur and Shih (2006); Supçiller and Çapraz (2011); Tseng and Lin (2005); Vahdani et al. (2015); Wu et al. (2009); Wu and Liu, (2011); Wu and Weng (2010); Y1ldiz and Yayla (2017) and Zeydan et al. (2011).

When the innovative and technology-intensive character of the ICT sector and the review findings are considered, supplier selection criteria for the ICT sector can be collected under the following 10 titles: Cost/Price, Quality, General Appearance, Delivery, Capabilities, Flexibility, Service, Innovation, Collaboration and Environment.

\section{METHODOLOGY OF THE STUDY}

The application performed in this study utilizes a comparative approach based on the sample data set obtained from the case company. Using the same data set, supplier selection and evaluation methodology of the case company is comparatively analysed against the frequently used multi-criteria methods ANP, TOPSIS, ANP-TOPSIS, and the proposed combined TOPSIS-(ANP-TOPSIS) results. This comparative methodology is depicted in Figure 1.

In the case company application, both criteria structure and firms' evaluation grades are discrete and identified. Therefore, in this study, it is prefered to use the above-mentioned frequently used pure multi-criteria methods instead of fuzzy methods. 


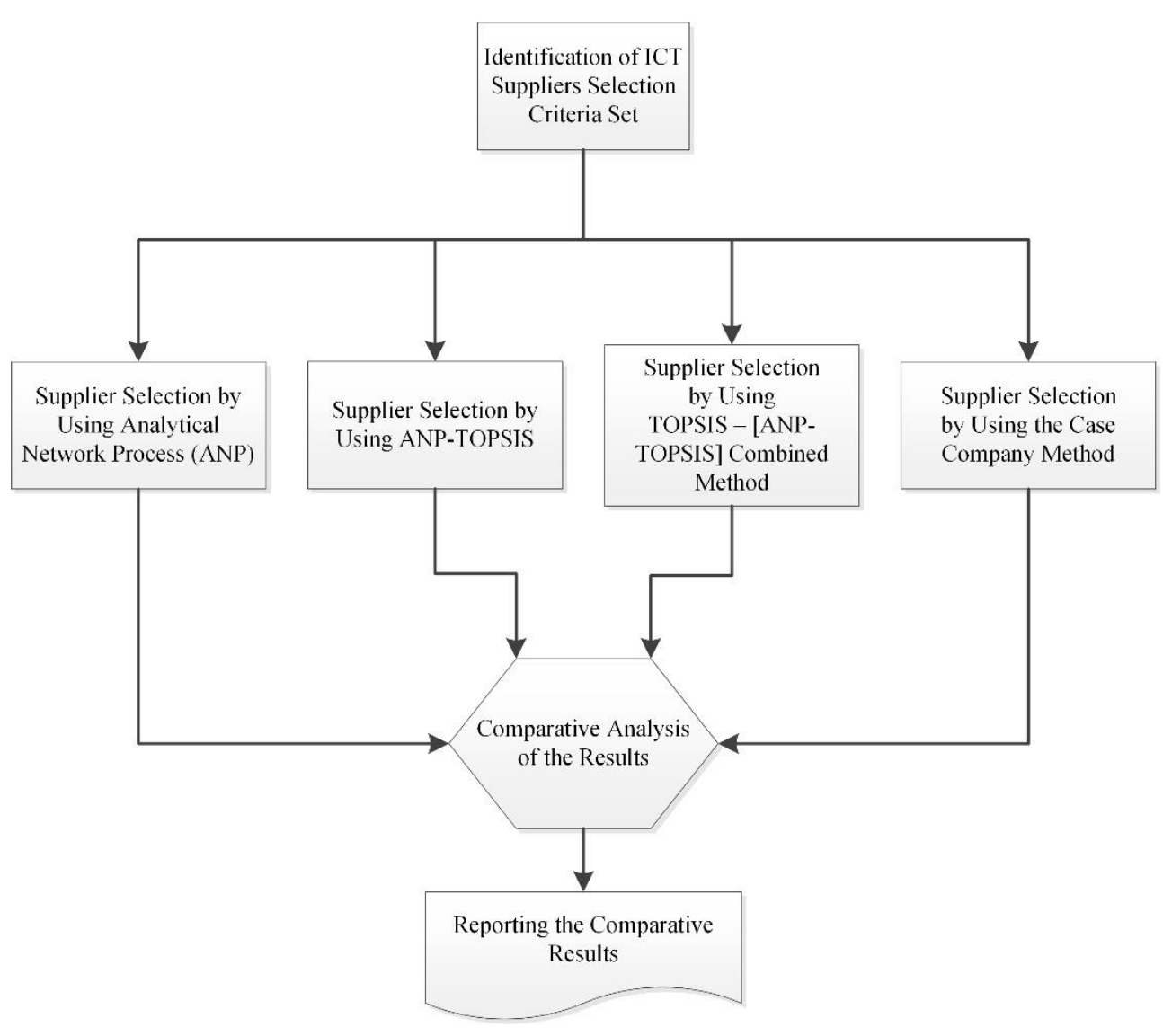

Figure 1. Methodology of the Study

Detailed steps of this comparative process are provided in the flowchart given in Figure 2. To be able to put forward the sensitivity of the results with respect to the criteria weights, this methodology is repeated with two different criteria weights. Based on the results of this comparative study, a generic model is suggested. 


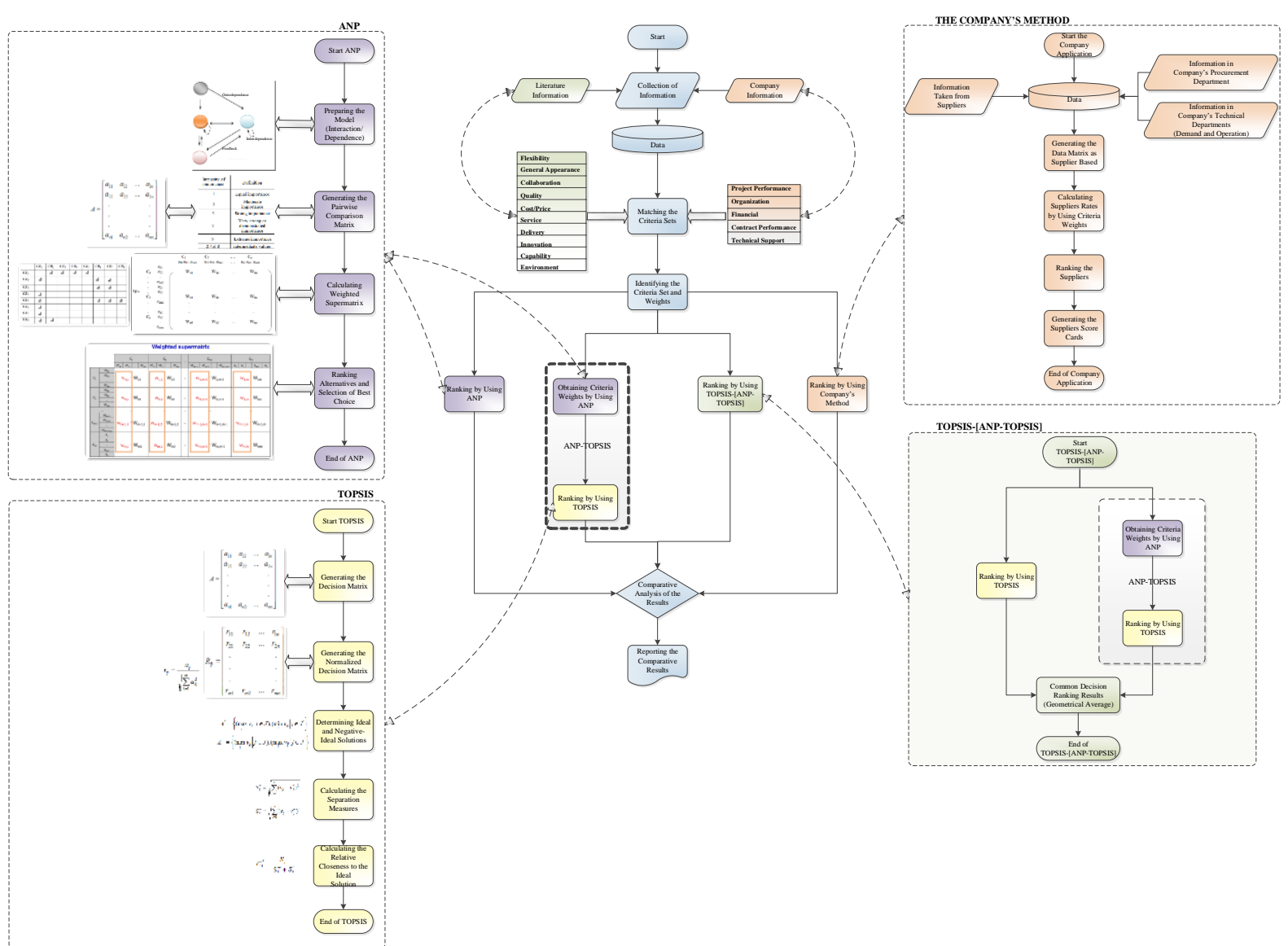

Figure 2. Detailed Steps of the Comparative Application Process

\section{EXISTING SUPPLIER SELECTION METHOD OF THE CASE COMPANY}

The case company analysed in this study operates in Turkey, and provides information and communication products and services. Within the organization structure, "Procurement and Supplier Management Department" is responsible from the inbound activities needed for operations. Within the scope of supplier management, this department is responsible from purchasing function as well as supplier ranking and selection activities for the suppliers from which hardware, software and service are procured. The procurement process is conducted in compliance with the procurement procedure of the company (ŞTP, 2015).

Supplier selection criteria used in the company are determined and evolved in time for the procurement of hardware, software and service. These criteria take into consideration the issues which are important from both Procurement Department's and requesting department's perspectives. During development of these criteria, not only Procurement Department's decisions considered, but also the opinions and feedbacks from the technical departments responsible from operations and maintenance of products and services are incorporated. These departments' effects on procedure are balanced in terms of evaluation. In this determination 
process, employees at different levels (i.e. experts, senior experts, managers and group managers) from related departments contribute to decision and consensus is achieved.

Table 2 provides the criteria groups and the sub-criteria with weights being used in the company with their respective weights.

Table 2. Criteria Groups and Weights Used by Company

\begin{tabular}{|c|c|c|}
\hline Criteria group & Sub-criteria & $\begin{array}{c}\text { Weight } \\
(\%)\end{array}$ \\
\hline \multirow[t]{11}{*}{ Project performance } & & 35 \\
\hline & Technology & 10 \\
\hline & Delivery in time & 15 \\
\hline & Delivery quality & 25 \\
\hline & Labour quality & 5 \\
\hline & Flexibility & 15 \\
\hline & Risk management & 5 \\
\hline & 2. Level supplier management & 5 \\
\hline & $\begin{array}{l}\text { Strategic partnership/ top management } \\
\text { commitment }\end{array}$ & 5 \\
\hline & Know how transfer & 5 \\
\hline & $\begin{array}{l}\text { Project management as compatible with } \\
\text { certification }\end{array}$ & 10 \\
\hline \multirow[t]{5}{*}{ Organization } & & 10 \\
\hline & Local organization & 30 \\
\hline & $R \& D$ capacity & 20 \\
\hline & Organizational stability & 20 \\
\hline & Local organization & 30 \\
\hline \multirow[t]{7}{*}{ Financial } & & 25 \\
\hline & Credit rating & 20 \\
\hline & The level of competitiveness & 50 \\
\hline & Industry ranking & 10 \\
\hline & Ecosystem & 5 \\
\hline & Billing & 10 \\
\hline & References & 5 \\
\hline \multirow[t]{3}{*}{ Contract performance } & & 15 \\
\hline & Commercial & 30 \\
\hline & Legal & 30 \\
\hline
\end{tabular}




\begin{tabular}{|c|c|c|}
\hline \multirow{7}{*}{ Technical support } & Contract flexibility & 40 \\
\hline & & 15 \\
\hline & SLA compatibility & 30 \\
\hline & Availability & 10 \\
\hline & Service of spare parts & 25 \\
\hline & Change and development capability & 15 \\
\hline & Quality of warranty & 20 \\
\hline
\end{tabular}

As for the reason for the project performance having the highest percent of $35 \%$, it can be argued that procurement activities in ICT sector are generally project-based activities involving software, hardware and service components. In such project-based procurement activities, supplier works as a partner, and its compatibility with the organization is of importance. Therefore, project performance stands out among the supplier selection criteria. It is also important to note that the sub-criteria used in the existing ranking are highly objective evaluations.

In this existing supplier selection methodology, evaluations are performed semiannually. Sub-criteria are graded out of 10 which are given by related departments of the company, and the linear calculation shown in Equation (1) leads to a supplier ranking score.

$$
\text { Ranking Score }=\sum_{i, j}\left(w_{i j} \cdot p_{i j}\right) ;\left\{\begin{array}{c}
\left(w_{i j} \mid \text { subcriteria weight }\right) \\
\left(p_{i j} \mid \text { supplier' s grade }\right) \\
i: \text { criteria group, } j: \text { subcriteria }
\end{array}\right.
$$

After these calculations, a scorecard is created for every supplier showing the scores for 5 criteria groups, and these grades are shown in the radar chart, as depicted in Figure 3. For each criteria group, suppliers' grades higher than the threshold are indicated by the dashed line. 


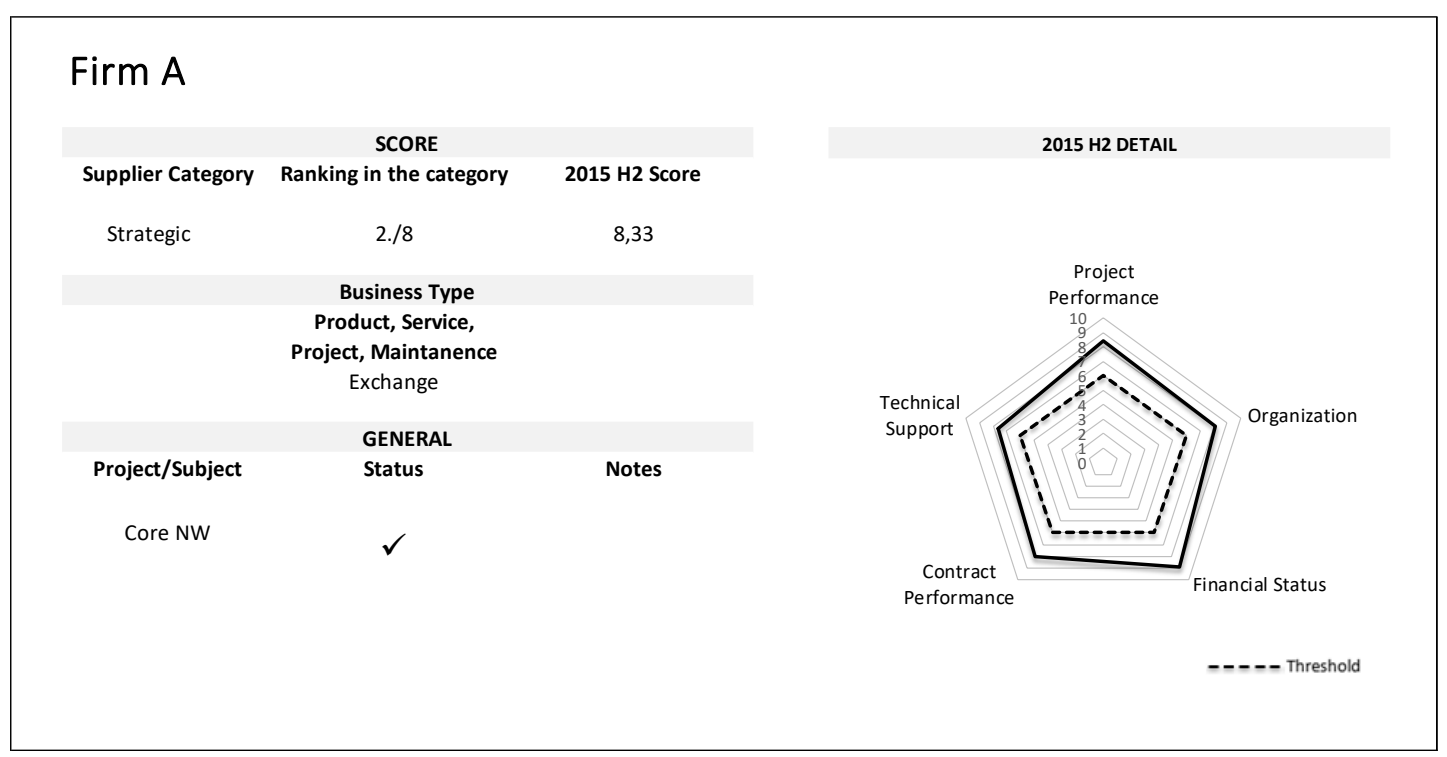

Figure 3. Supplier Evaluation Score Card

In this radar chart, each criteria group is represented on a separate axis, and the overall score for each criteria group is shown on the relevant axis. The threshold level of 6 (out of 10) is also shown in this chart. Hence, this chart provides an easy-to-understand and visual representation in multiple dimensions, and showing the dimensions at which the supplier is strong or weak. According to these evaluation graphs, issues that have to be improved for each supplier is determined. Feedback and targets for improvement opportunities are provided to the supplier. Evaluation results are updated and recorded.

Companies seek to procure products from a pool of alternative suppliers (Honhon et al., 2012), hence such detailed score cards obtained meet the need for selecting the appropriate supplier.

A sample data set used in this existing methodology stated above is obtained from the company, and it is used for the comparative application in the rest of this study.

\section{MAPPING OF THE CRITERIA USED IN THE CASE COMPANY ONTO CRITERIA FROM LITERATURE}

The first step of the flowchart given in Figure 2 is the determination of the selection criteria. Since there exists a multiplicity of criteria and sub-criteria in the literature as well as many overlapping classifications, a simplification and grouping study is done for the criteria existing in the literature. Criteria representing the same concept but appearing under different 
names are renamed and collected under a common name. Overlapping and conflicting subcriteria are also simplified and collected under the simplified common criteria groups.

After this simplification and grouping, 541 sub-criteria are reduced to 94, and 36 criteria groups are reduced to 10, resulting in the criteria: general appearance of the company, cost/price, delivery, quality, capability, service, flexibility, innovation, collaboration and environment.

Based on this simplification, mapping/matching of the criteria and weights used in the case company onto the set obtained from literature is performed and indicated in Figure 4. While performing this mapping, sub-criteria under each group are transferred to its relevant position in the new classification with their own weights. Eventually final/ultimate weights are obtained by reflecting its effect in proportion to the weight of the criteria group in which they belong in the original company weighting. 


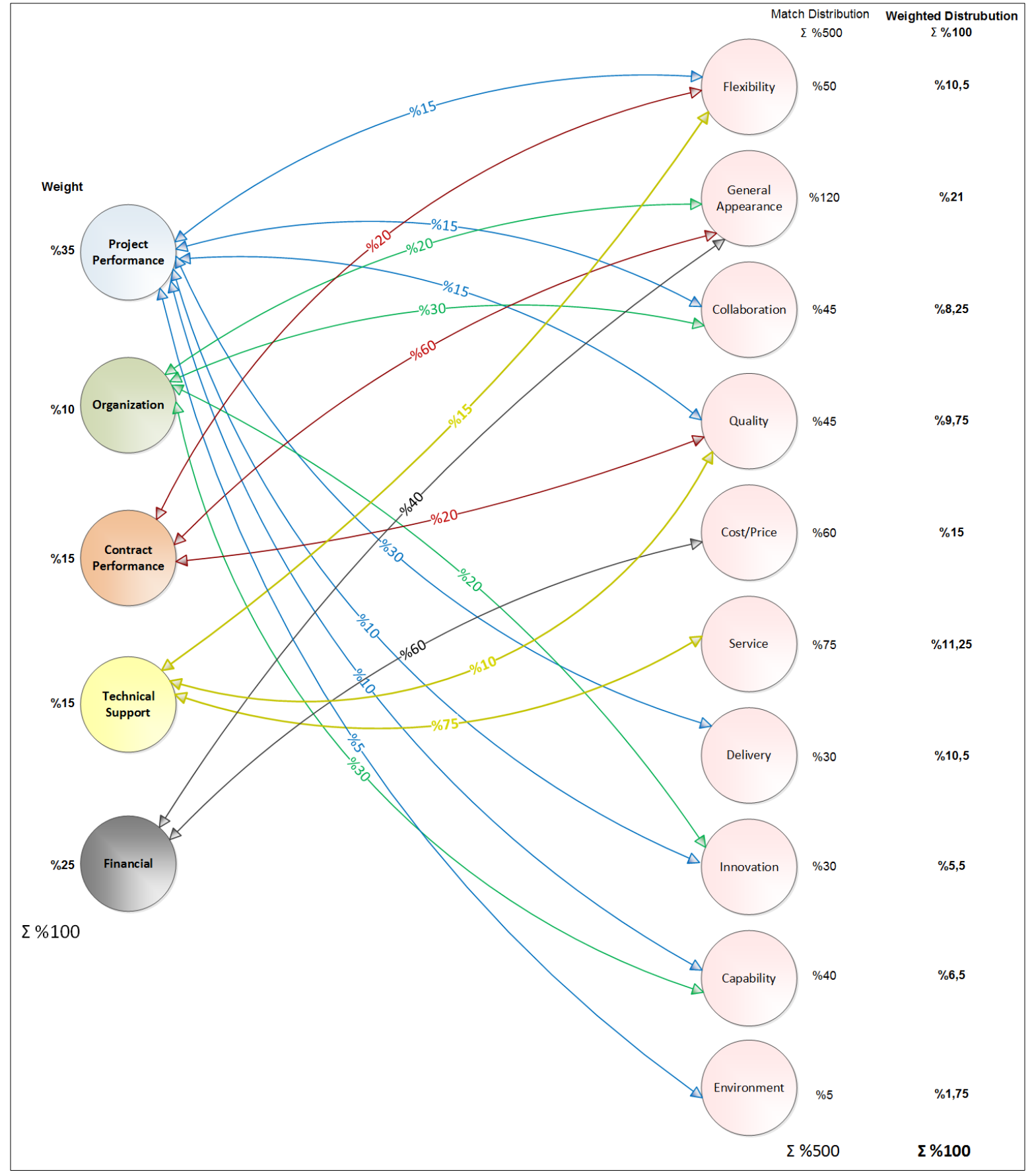

Figure 4. Mapping of the Company Criteria and Weights onto the Literature Criteria Set

In this mapping, general appearance of the company has the highest weight, and the other criteria can be classified under two supergroups of "traditonal criteria" and "contemporary criteria", leading to the criteria hierarchy given in Figure 5. It is evident that the contemporary criteria such as innovation, flexibility and collaboration assume a special importance for the technology-intensive sectors like ICT. Hence, such a top-level classification is considered appropriate. 


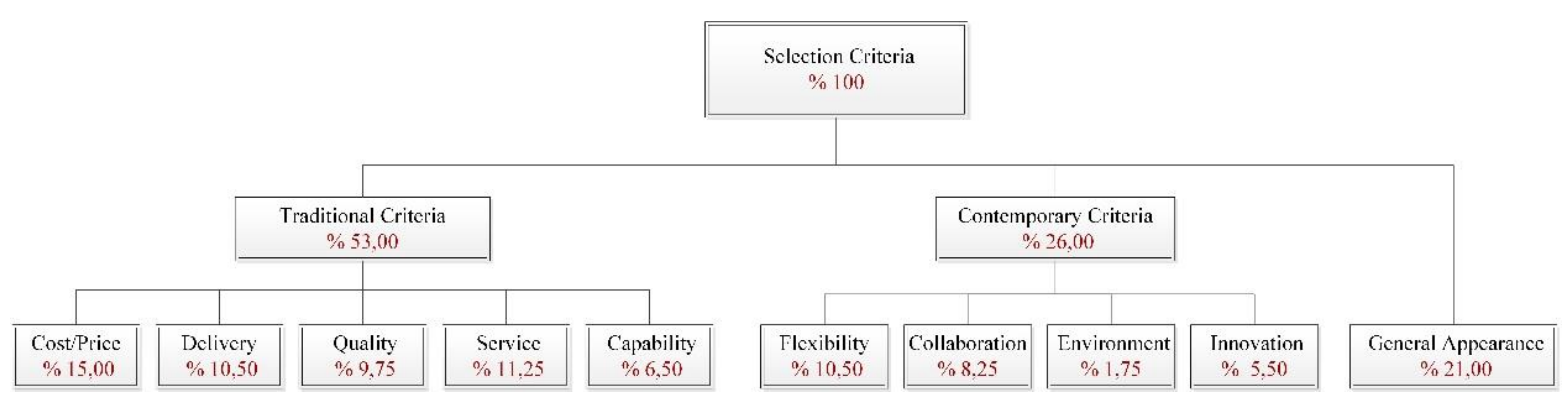

Figure 5. Upper Level Hierarchical Structure of the Literature Criteria Groups (Weights Indicated)

\section{THE COMPARATIVE STUDY AND RESULTS}

Using the sample data set belonging to 8 strategic suppliers, the methodology given in Figure 2 is executed. Results are obtained for TOPSIS, ANP-TOPSIS and proposed combined TOPSIS-[ANP-TOPSIS] methods for both existing criteria set and the criteria set obtained from literature. While obtaining the results for the proposed combined TOPSIS-[ANPTOPSIS] methodology, geometric average of the TOPSIS and ANP-TOPSIS results is used, as given in Equation 2. The geometric average was also used in the study by Shyur and Shih (2006) for joint decision making.

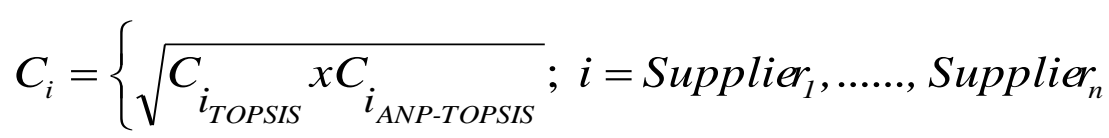

According to the application process given in Figure 2, TOPSIS and ANP-TOPSIS results are calculated first. Obtaining the results for the proposed methodology structurally requires the execution of ANP and TOPSIS. Therefore, for the sake of compactness, Table 3 provides comparative summary of the results for the method used in the case company and the proposed method only.

In these combined model applications, implementations were done by authors using the criteria weights which are determined by company's procurement and related technical departments, and sample firms' evaluation data which were also determined by the same departments. 
Table 3. TOPSIS - [ANP-TOPSIS] Combined Models' Results by Using Company and Literature Criteria Set

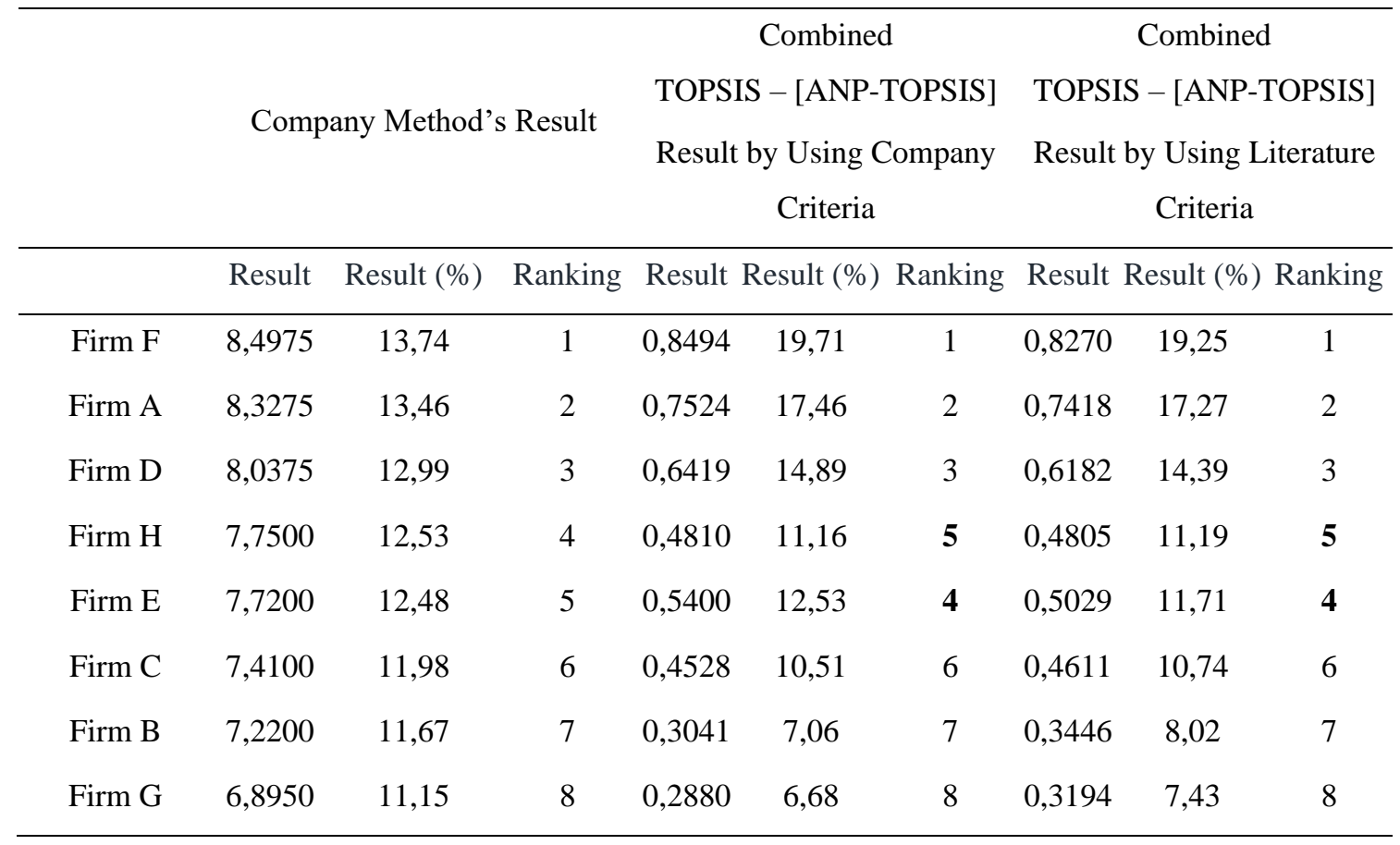

According to the results provided in Table 3, the use of both criteria sets led to the same ranking in combined TOPSIS- [ANP-TOPSIS] methodology. Results are generally compatible with the existing methodology of the company, along with a one difference: the suppliers at the 4th and 5th ranking swapped their positions with very minor difference in their grade points. Figure 6 shows these results graphically. 


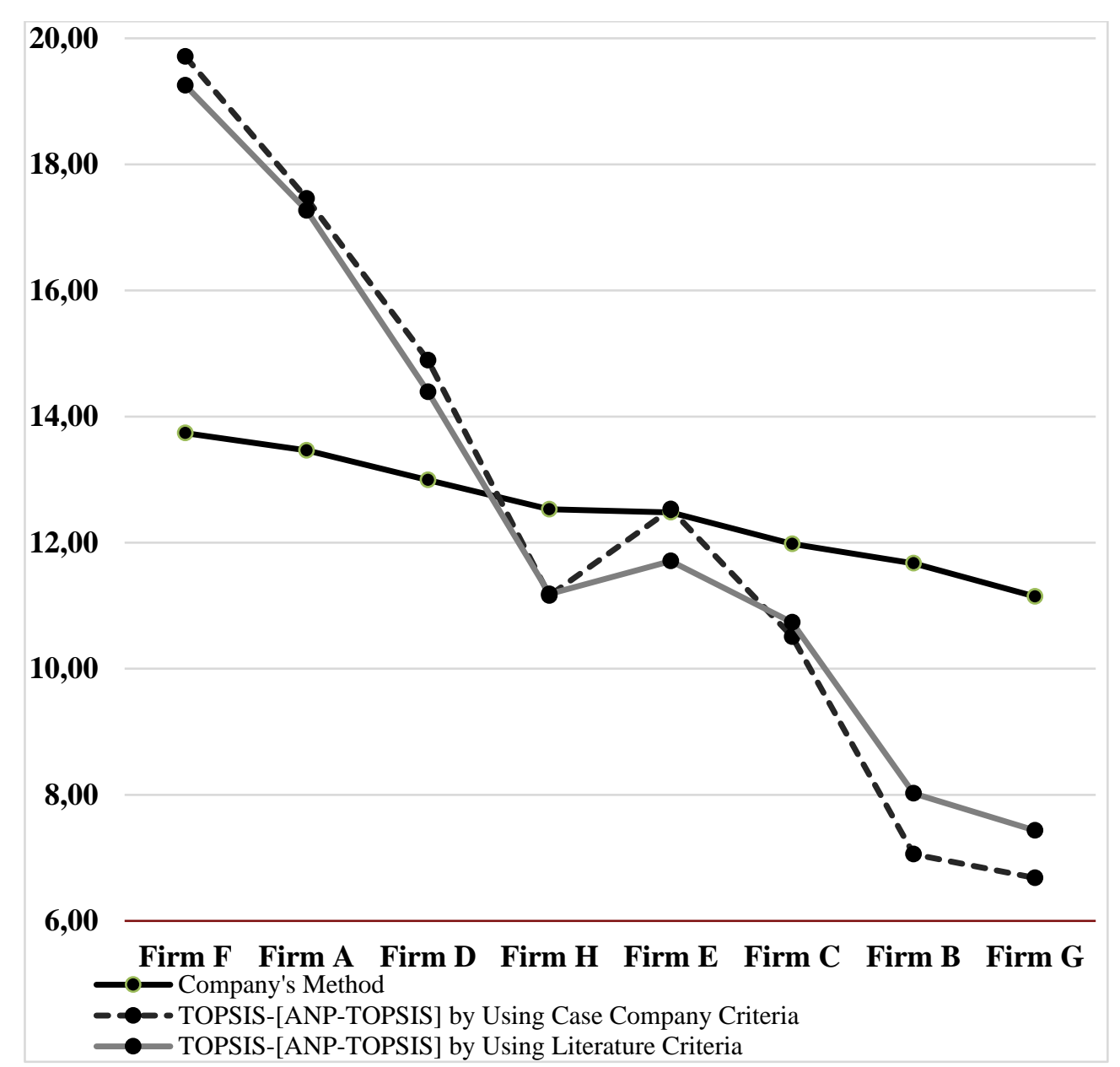

Figure 6. TOPSIS - [ANP-TOPSIS] Combined Methods' Results by Using Case Company and Literature Criteria

In this graph, it is seen that similar ranking results are obtained with two different criteria sets despite some deviations. The proposed combined model led to results compatible with the company application for the first three and the last three suppliers. Ranking positions of only Firm $\mathrm{H}$ and Firm E have changed. Hence, it can be argued that proposed integrated TOPSIS[ANP-TOPSIS] method demonstrated higher discriminatory power in case of supplier gradings which are close to each other.

After completing this comparison, the criteria weights are modified and an investigation is made into any change in the behaviour of these models. Weights provided in Figure 5 criteria hierarchy are modified as given in Figure 7, and the entire comparative process is repeated with the new weights. In this weight modification, weight of the traditional criteria are reduced from $\% 53$ to $\% 45$, weights of the contemporary criteria are increased from $\% 26$ to $\% 40$, and weight of the general appearance is reduced from $\% 21$ to $\% 15$. While distributing these new weights to sub-criteria, original proportions are preserved. 


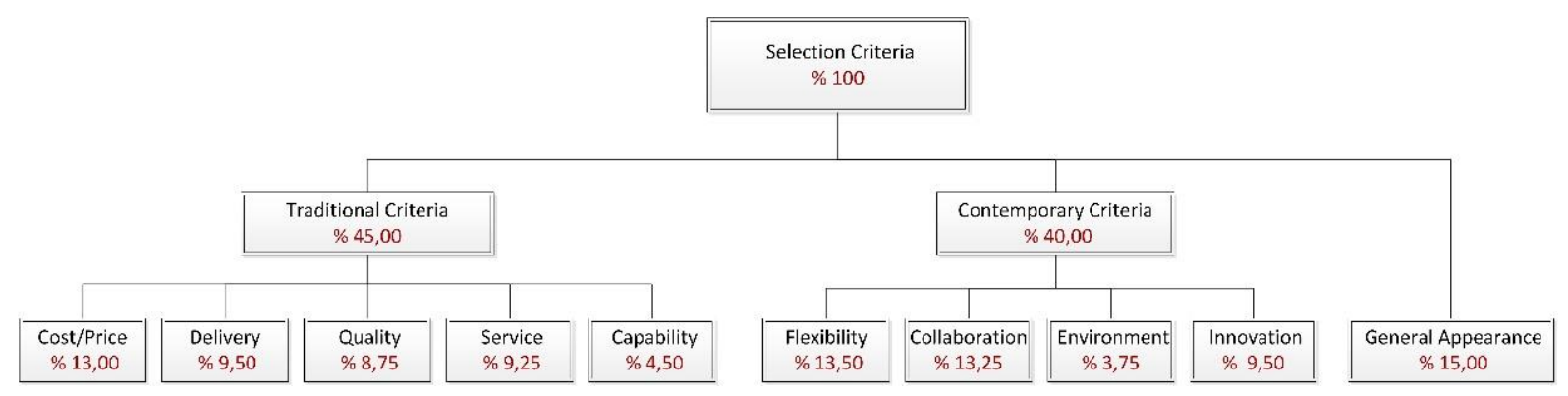

Figure 7. Criteria Hierarchy and Weight Distribution after Changing Weights

While deciding on the new weight set, the following are taken into consideration: a) comtemporary character of the ICT sector, b) increasing importance of collaboration, innovation, flexibility and environmental factors. Please note that this hierarchy and weight distribution is selected mainly for the sensitivity analysis purposes. Undoubtedly, different classifications and weighting schemes can be selected and utilized in different company applications.

As it can be seen from the above figure, the weight of the contemporary criteria having a special importance for ICT are increased, and weigths of the traditional criteria and general appearance criterion are reduced proportionally. The results of the comparative study obtained with the modified weights are provided in Table 4.

Table 4. TOPSIS - [ANP-TOPSIS] Combined Models' Results by Using Changed Weights Combined TOPSIS - [ANP- Combined TOPSIS - [ANPTOPSIS] TOPSIS]

Company Method's Result

Result by Using Company

Criteria
Result by Using Literature

Criteria

\begin{tabular}{|c|c|c|c|c|c|c|c|c|c|}
\hline & Result & Result (\%) & Ranking & Result & Result (\%) & Ranking & Result & Result (\%) & Ranking \\
\hline Firm F & 8,5143 & 13,74 & 1 & 0,8270 & 19,25 & 1 & 0,8149 & 19,17 & 1 \\
\hline Firm A & 8,3701 & 13,50 & 2 & 0,7418 & 17,27 & 2 & 0,7817 & 18,39 & 2 \\
\hline Firm D & 8,0473 & 12,98 & 3 & 0,6182 & 14,39 & 3 & 0,6270 & 14,75 & 3 \\
\hline Firm $\mathrm{H}$ & 7,7605 & 12,52 & 4 & 0,4805 & 11,19 & 5 & 0,4730 & 11,13 & 4 \\
\hline Firm E & 7,7154 & 12,45 & 5 & 0,5029 & 11,71 & 4 & 0,4617 & 10,86 & 5 \\
\hline Firm C & 7,4236 & 11,98 & 6 & 0,4611 & 10,74 & 6 & 0,4488 & 10,56 & 6 \\
\hline Firm B & 7,2206 & 11,65 & 7 & 0,3446 & 8,02 & 7 & 0,3420 & 8,05 & 7 \\
\hline Firm G & 6,9350 & 11,19 & 8 & 0,3194 & 7,43 & 8 & 0,3012 & 7,09 & 8 \\
\hline
\end{tabular}


According to the results given in Table 4, application of the suggested combined method led to a swap in the 4th and 5th ranks, whereas application with the modified weight set gives the same ranking result with the company application. Figure 8 provides a comparative graph of these results.

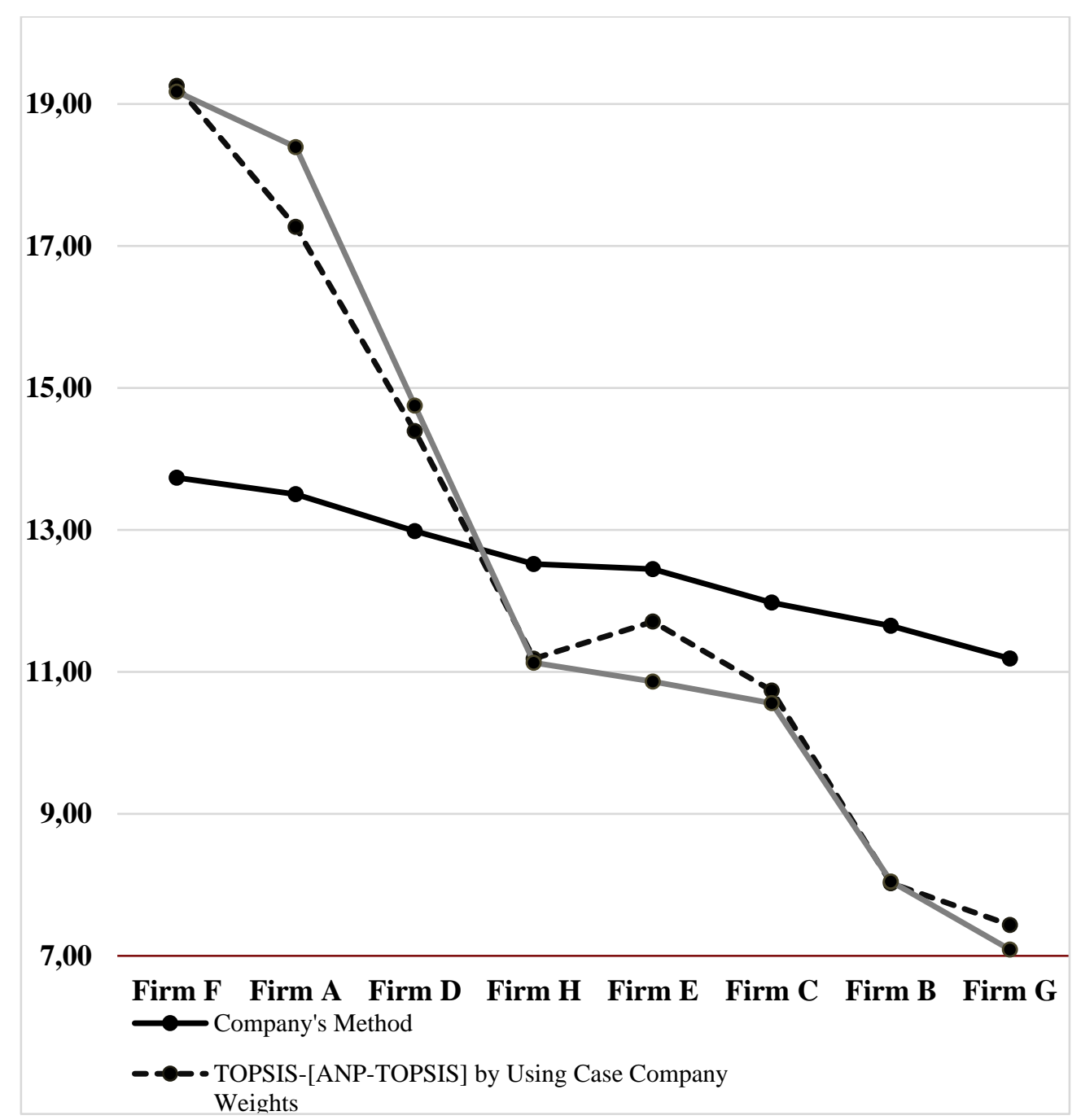

Figure 8. TOPSIS - [ANP-TOPSIS] Combined Models' Results by Using Company and Changed Literature Weights

As it can be seen from the Figure 8, a ranking similar to the company's current application which is obtained when the weight of the contemporary criteria are increased. In the company application, the grading difference between Firm E and Firm $\mathrm{H}$ is a very small, which is $\% 0,07$. For the application of the proposed integrated model, this difference is $\% 0,27$, which is a more discriminatory result. Hence, it can be argued that the applied criteria set 
together with the proposed integrated method exhibits somewhat more discriminatory power for the ranking results. This characteristic is highly important for the suppliers which receive closer grades to each other. Hence, managers can obtain a better picture of suppliers having performance gradings very close to each other.

\section{A GENERIC SUPPLIER SELECTION MODEL PROPOSAL}

Based on the application methodology and the comparative study offered upto so far, this section offers a generic supplier selection model including the following 4 main steps:

I) Mapping of the existing company criteria onto the criteria existing in literature.

II) Obtaining the ranking results by applying each one of: a) existing company methodology, b) ANP, c) ANP-TOPSIS, and d) TOPSIS-[ANP-TOPSIS].

III) Comparatively analysing the results obtained from these methods, and making a managerial decision for the method to be used in the supplier selection.

IV) Performing the supplier selection according to the method selected.

Flowchart for this generalized process is given in Figure 9 along with the all steps. 


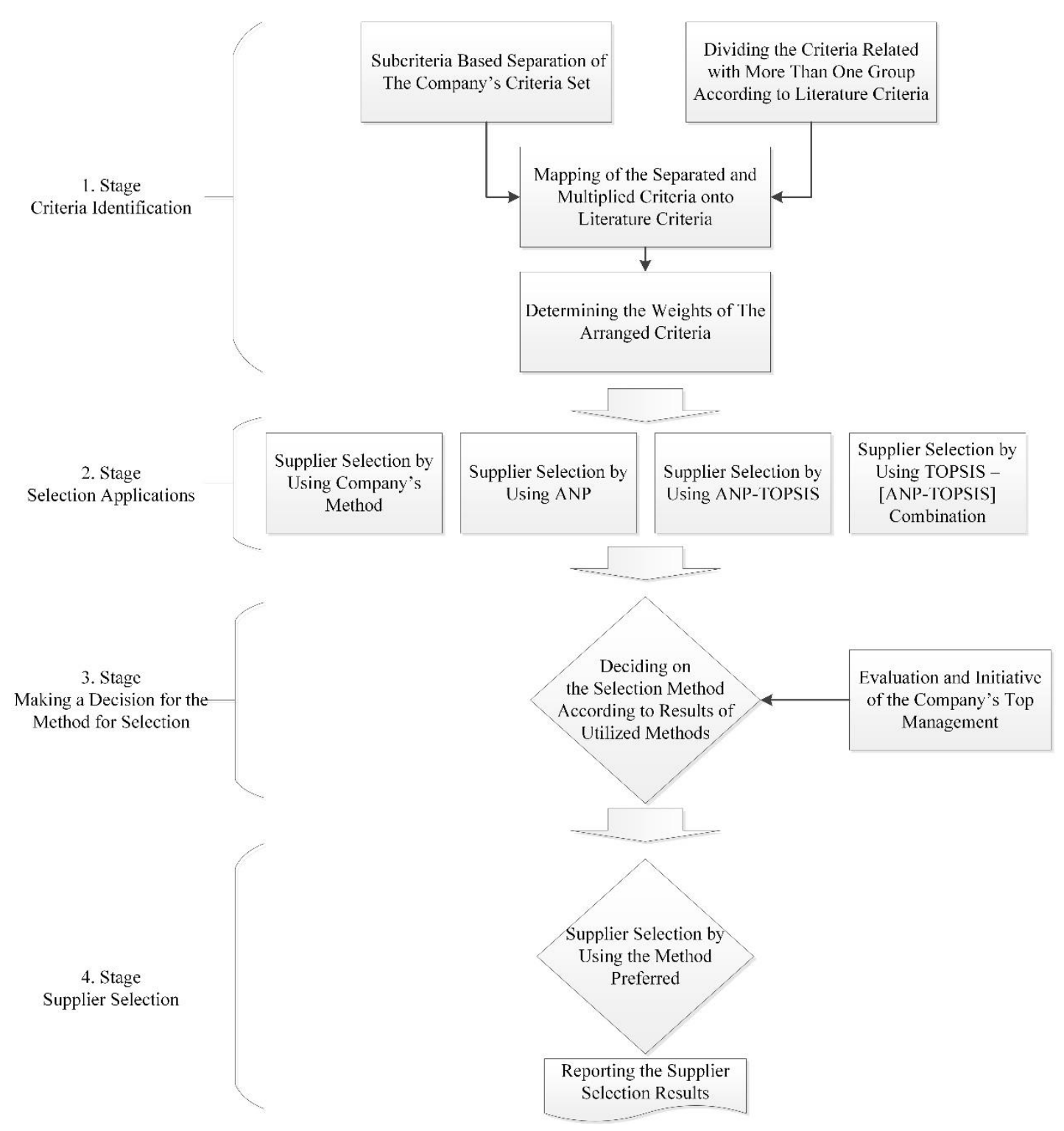

Figure 9. Steps of the Generalized Supplier Selection Process

This generalization and the generalized decision support system offered in the remainder of this section are meaningful, since:

- Frequent use and practicality of ANP and TOPSIS methods in different contexts are well-proven.

- The need to make comparisons among the results of multiple methods for strategic decision support is true for any sector or context.

- Seeing the effects of different weight sets on the selection results is required in any context.

- Having a flexible design in fast comparative evaluations can be made in a visually attractive and practical manner is needed for any sector or context. 
In this generic process, deciding on the appropriate method to be used for the supplier selection takes into consideration the comparative results of all of the applied methods, as well as the evaluation and initiatives of the top management. This provides objectivity of the comparative results while giving enough room for any additional top-level concerns that can be in question to be involved in the process. At this point, reporting and presentation of the comparative results of different methods, both numerically and graphically, is of significant importance for decision makers for making correct evaluations. Hence, the comparative process offered in Figure 9 can be further transformed into a decision support system which provides automation for the mechanical calculations needed for each model, and enables comparative evaluation of the results in a dynamic, automated and integrated manner. Such a system enables a decision support environment in which results of different methods can be obtained and evaluated rapidly. Modular and customizable designs can be developed according to the requirements of different sectors and companies by using different software application development tools.

A generic and conceptual automation system design for supplier selection is offered in Figure 10. This system is applicable in the selection of the strategic suppliers providing end-toend solutions for the procurement of project-based hardware, software and integration service. 


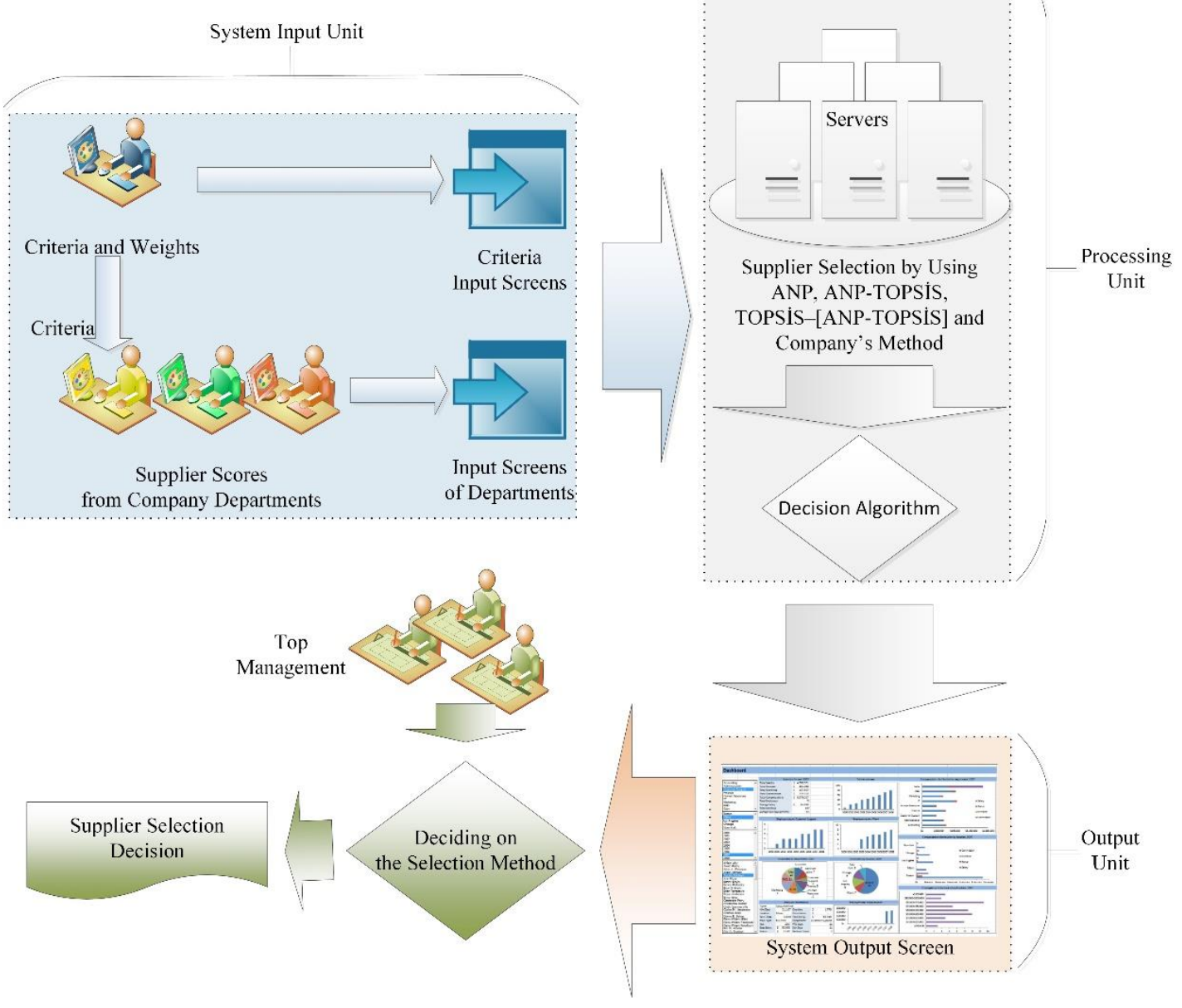

Figure 10. Generalized Automation System for Supplier Selection

As it can be seen from the Figure 10, the proposed automation system contains three main components: system input unit, processing unit and output unit.

System input unit contains the data entry screens from which criteria to be used, weights and the grade points received for each supplier are entered into the system. During this entry, Procurement Department enters the criteria to be used, related weights and the grading; and technical units enter the grading for technical criteria. Upon completion of the data entry, the processing unit has the required data to execute different selection applications.

In the processing unit, ANP, ANP-TOPSIS, TOPSIS-[ANP-TOPSIS] and company methods are applied separately. Ranking results from each method are send to a decision algorithm within the same environment for simultaneous and automated evaluation. This decision algorithm can be designed flexibly depending on the special requirements and needs of the ICT sector or any other different sector. A sample algorithm to be used can be checking the supplier ranking positions obtained in different methods, and placing the supplier to the 
ranking position which appears the most in different rankings. Another algorithm can be getting the geometric averages of the results of different methods and making a final ranking accordingly. Thus, the designed decision algorithm can consider the results of multiple methods. Different methods other than ANP, ANP-TOPSIS, TOPSIS-[ANP-TOPSIS] can also be included in this comparative systematic if required. Consequently, this generic model can be customized to incorporate any other multi-criteria method, depending on the company needs.

The output unit provides the necessary user interface for reporting and displaying the results of the individual methods and the decision algorithm both numerically and graphically. This serves as a dashboard for top management decision support. Based on the results in the display, decision makers can apply the selected method directly; or they can try different combinations of the methods and make their final decisions after evaluating the results of different scenarios as well.

In this system, the basic characteristic of a such dashboard is able to provide summary information from multiple methods in an easy-to-understand and dynamic manner. The presence of visual components, such as different user-friently graphical designs, along with the numerical data is critical in the design of these special dashboards. A sample managerial dashboard design acting as a user interface for managerial level is given in Figure 11.

As it can be seen from the Figure 11, this dashboard contains 3 sections: The first section offers the summary results of each applied method in the form of both tables and line graphs. Methods are positioned vertically one under the other with their numerical and visual details. In this summary dashboard, a consistence index is also reported indicating how many suppliers are ranked in compatibility with the company's original ranking. The second section contains comparative results of different methods in one line graph, to provide an effective and visual evaluation of multiple results in an integrated manner.

Third section of the dashboard is designed to reveal the numerical and graphical results of different alternative scenarios preferred by the management. Two of the decision algorithms defined in the system can be selected from a drop-down list, and the results can be reported simultaneously.

Such a dashboard design provides simultaneous reporting of the results of multiple methods in a dynamic and visually striking manner. This gives managers an effective base for rapid comparative evaluation, and enables further managerial evaluations and initiatives to be 
included into the process. Hence, such a dynamic decision-support system will lead to better decision making.

Generic structure described in this section enables different decision algorithms as well as dashboard designs to be incorporated into the system. Updating the utilized set of criteria, weights and supplier gradings calculated in terms of the utilized criteria plays utmost importance in this system which acts as a strategic decision-making mechanism. Considering the fast-changing nature of the ICT sector, the system should refresh at least two times in a year. Refreshing frequencies of 3-months or 4-months can also be determined and put into use depending on the strategic view of the company and the dynamics of the sector in which the system is used.

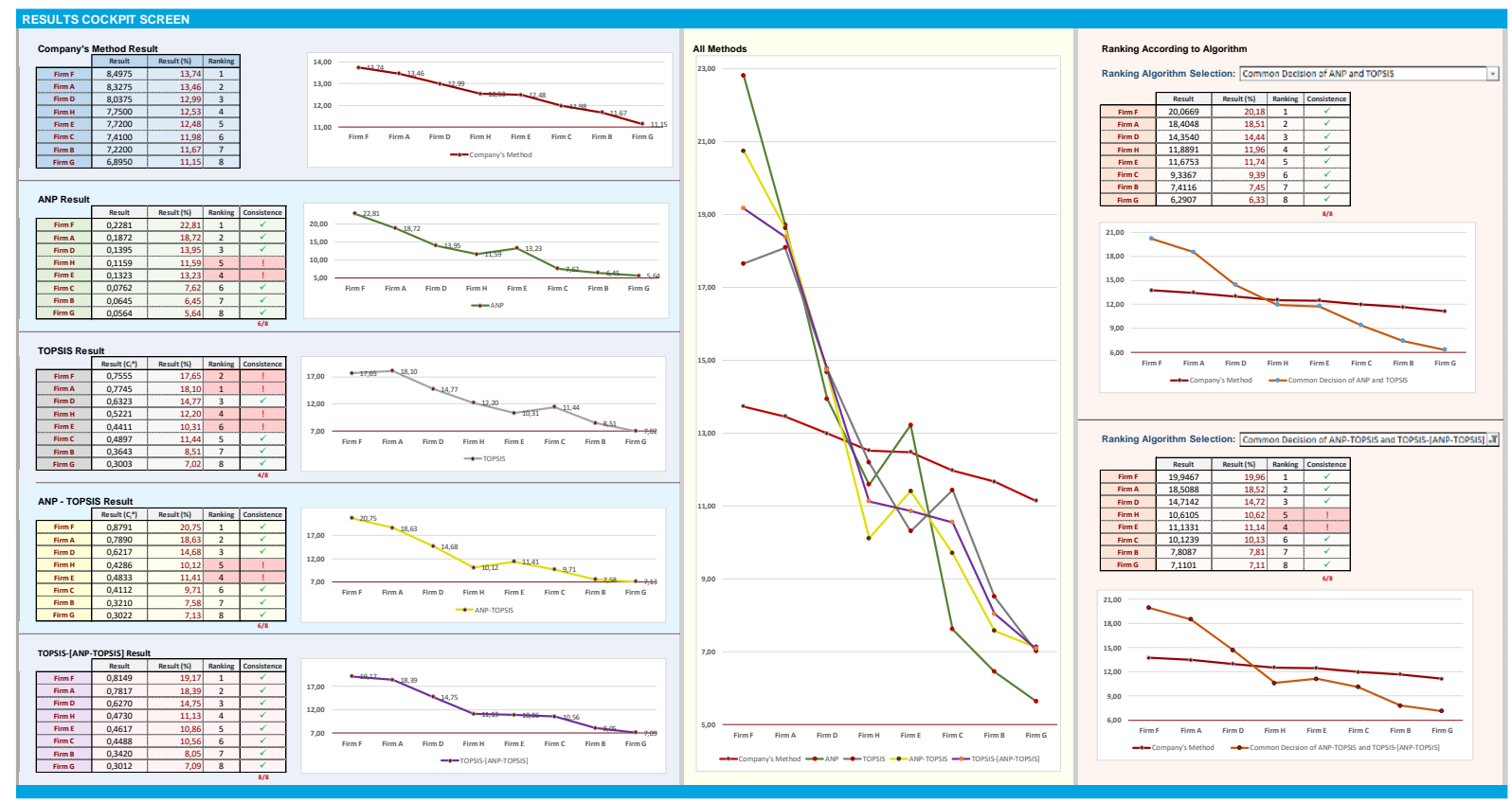

Figure 11. A Sample Managerial Dashboard Design for Top-Management Decision Support (User Interface for the Top Managers)

\section{CONCLUSION AND FUTURE RESEARCH SUGGESTIONS}

In this study, a generic supplier selection model and the related conceptual decision support system are proposed. Utilizing the sample data obtained from a Turkish case company working in ICT sector, a comparative study is made for supplier ranking and selection utilizing various multi-criteria methods. Based on the results of the comparative study, a generic model and a conceptual design for a decision support system is proposed. The suggested system has the flexibility to incorporate different multi-criteria models as well as different dashboard designs to meet the requirements of different sectors and companies. The criteria hierarchy used 
in this study highlighted the importance of contemporary criteria such as innovation and collaboration. This study also highlighted the strategic and mission-critical role of suppliers and supplier selection processes, especially for ICT sector in which suppliers should act as longterm partners for the company.

It is important to note that the methodology used in this study clearly considers the need for a dynamic and visually striking decision support in comparing the results of different methods and weight sets.

The comparative application study and the generic proposed model contribute to literature for the following aspects:

- Combined TOPSIS - (ANP-TOPSIS) approach is offered, utilizing the geometric average of the TOPSIS and ANP-TOPSIS results. By this combination, criteria interactions are handled by ANP, and ideal solution mechanism of TOPSIS is incorporated into the methodology.

- A new set of criteria and weight set which can be used in the ICT companies for strategic supplier selection is offered. These new criteria and weights are also applicable in other technology-intensive sectors, and can shed light to the development of different contemporary weight sets.

- A generic application model and conceptual design of a dynamic automation system leading to decision support is proposed. This model along with the dashboard logic provided is applicable to ICT as well as other sectors, since it is based on the frequentlyused multi-criteria models in combination with the criteria set adopted from literature and real case.

Hence, this study is important in terms of generalizing a case-based comparative study into a generic model together with dynamic dashboarding and decision-support capabilities for upper-management decision-making. Conceptual and generic dashboard design provides a rapid, dynamic and integrated environment for the upper management, and sample given can sparkle various different managerial support panel designs. Since the decision support system offered in this study is at the conceptual level, this study can be used as a system analysis document for the development of the related application software. With these characteristics, the study contributes to practitioner's perspective and can shed light for the development of conteporary weight sets and dashboard designs. 
In future research, more detailed studies can be made on selection algorithms to develop different combinations of the other existing multi-criteria methods in the literature. Application of the proposed model in different sectors will be valuable, and such studies can accumulate and lead to a clear picture for the comparative behaviour of the model in multiple sectors. Applications in different sectors will be valuable, especially for the health and defence sectors in which the decisions are vital and suppliers assume a strategic role. Due to the project-based character and its increasing global mission-critical role, further studies and applications in energy sector can also be valuable contributions to literature.

To sum up, this study has the potential to contribute to the researchers, practitioners and managers as well as application developers for further research by its generic and flexible character. 


\section{REFERENCES}

Alyanak, G., and Armane, Ö. (2009). An integrated supplier selection and order allocation approach in a battery company, Endüstri Mühendisliği Dergisi, 19(4), 2-19.

Amin, S. H., and Razmi, J. (2009). An integrated fuzzy model for supplier management: a case study of ISP selection and evaluation, Expert Systems with Applications, 36(4), 8639-8648.

Amin, S. H., and Zhang, G. (2012). An integrated model for closed-loop supply chain configuration and supplier selection: multi-objective approach, Expert Systems with Applications, 39(8), 6782-6791.

Ar, M. İ., Gökşen H., and Tuncer, M. A. (2015). Kablo sektöründe tedarikçi seçimi için bütünleşik DEMATELAAS-VIKOR yönteminin kullanılması, Ege Akademik Bakış, 15(2), 285-300. [in Turkish]

Boer L., and Wegen, L. M. (2003). Practice and promise of formal supplier selection: a study of four empirical cases, Journal of Purchasing \& Supply Management, 9(3),109-118.

Borges de Araújo, M. C., L. H. Alencar, and Viana, J. C. 2015. Structuring a model for supplier selection, Management Research Review, 38(11), 1213-1232.

Brosig-Koch, J., and Heinrich, T. (2014) Reputation and mechanism choice in procurement auctions: an experiment, Production and Operations Management, 23(2), 210-220.

Carter J. R., A. Maltz, E. Maltz, M. Goh, and Yan, T. (2010). Impact of culture on supplier selection decision making, The International Journal of Logistics Management, 21(3), 353-374.

Chan, F. T. S. (2003). Interactive selection model for supplier selection process: an analytical hierarchy process approach, International Journal of Production Research, 41(15), 3549-3579.

Chan, F. T. S., and Chan, H. K. (2004). Development of the supplier selection model - a case study in the advanced technology industry, Journal of Engineering Manufacture, 218(12), 1807-1824.

Chen, P. S. and Wu, M. T. (2013). A modified failure mode and effects analysis method for supplier selection problems in the supply chain risk environment: a case study, Computers \& Industrial Engineering, 66(4), 634-642.

Chen, K. L., C. C. Yeh, and Huang, L. C. (2014). Supplier selection using a hybrid model for 3C industry, Journal of Business Economics and Management, 14(4), 631-645.

Chou, S. Y., and Chang, Y. H. (2008). A decision support system for supplier selection based on a strategy-aligned fuzzy SMART approach, Expert Systems with Applications, 34(4), 2241-2253.

Erdal, M. (2011). Satın Alma ve Tedarik Zinciri Yönetimi. İstanbul, Turkey: Beta Basım. [in Turkish]

Fazlollahtabar, H., I. Mahdavi, M. T. Ashoori, S. Kaviani, and Mahdavi-Amiri, N. (2011). A multi-objective decision-making process of supplier selection and order allocation for multi-period scheduling in an electronic market, International Journal of Advanced Manufacturing Technology, 52(9-12), 1039-1052.

Golmohammadi, D. (2011). Neural network application for fuzzy multi-criteria decision making problems, International Journal of Computer Integrated Manufacturing, 131(2), 490-504. 
Honhon, D., V. Gaur and Seshadri, S. (2012). A multi-supplier sourcing problem with a preference ordering of suppliers, Production and Operations Management, 25(3), 477-497.

Hruska R., P. Prusa, and Babic, D. (2014). The use of AHP method for selection of supplier, Transport, 29(2): 195-203.

Hsu, C. C., V. R. Kannan, G. H. Leong, and Tan, K. C. (2006). Supplier selection construct: instrument development and validation, The International Journal of Logistics Management, 17(2), 213-239.

Huang, J. D. and Hu, M. H. (2013). Two-stage solution approach for supplier selection: a case study in a Taiwan automotive industry, International Journal of Computer Integrated Manufacturing, 26(3), 237-251.

Huang, S.H. and Keskar, H. (2007). Comprehensive and configurable metrics for supplier selection, International Journal of Production Economics, 105(2), 510-538.

Igarashi M., L. Boer and Fet, A. M. (2013). What is required for greener supplier selection? a literature review and conceptual model development, Journal of Purchasing \& Supply Management 19(4), 247-263.

Ispat. (2014). Information and Communication Technologies. Ankara, Turkey: A report commissioned by Investment Support and Promotion Agency of Turkey (ISPAT).

Ispat. (2017). Information and Communication Technologies. Ankara, Turkey: A report commissioned by Investment Support and Promotion Agency of Turkey (ISPAT).

ITU. 2016. ICT Facts and Figures, Geneva, Switzerland: The International Telecommunication Union.

Jadidi O., T. S. Hong, and Firouzi, F. (2009). TOPSIS extension for multi-objective supplier selection problem under price breaks, International Journal of Management Science and Engineering Management, 4(3), 217229.

Kasirian, M. N., and Yusuff, R.M. (2013). An integration of a hybrid modified TOPSIS with a PGP model for the supplier selection with interdependent criteria, International Journal of Production Research, 51(4), 10371054.

Kumar S., Kumar S., and Barman, A.G. (2018). Supplier selection using fuzzy TOPSIS multi criteria model for a small scale steel manufacturing unit, Procedia Computer Science, 133, 905-912.

Kumar, M., Vrat, P., and Shankar, R. (2004). A fuzzy goal programming approach for vendor selection problem in a supply chain, Computer and Industrial Engineering, 46 (1), 69-85.

Kuo R. J., L. Y. Lee, and Hu, T. L. (2010a). Developing a supplier selection system through integrating fuzzy AHP and Fuzzy DEA: a case study on an auto lighting system company in Taiwan, Production Planning \& Contro,l 21(5), 468-484.

Kuo, R. J., Y. C. Wang, and Tien, F. C. (2010b), Integration of artificial neural network and MADA methods for green supplier selection, Journal of Cleaner Production, 18(12), 1161-1170.

Kuo, R. J., and Lin, Y. J. (2012). Supplier selection using analytic network process and data envelopment analysis, International Journal of Production Research, 50(11), 2852-2863.

Liao, A. K., K. L. Chang, and Tzeng-Wei, T. (2010). Optimal selection of program suppliers for TV companies using an analytic network process (ANP) approach, Asia-Pacific Journal of Operational Research, 27(6), 753-767. 
Lin, C. T., C. B. Chen and Ting, Y. C.. (2011). An ERP model for supplier selection in electronics industry, Expert Systems with Applications, 38(3), 1760-1765.

Madhukant, J. (2009). Retail Management. India: Gennext Publication.

Matopoulos A., J. E. Bell, and Aktas, E. (2016). The use of modelling in purchasing/supply management research, Journal of Purchasing \& Supply Management, 22(4), 262-265.

Narasimhan, R., S. Talluri, and Mendez, D. (2001). Supplier evaluation and rationalization via data envelopment analysis: an empirical examination, The Journal of Supply Chain Management, 2001 (Summer), 28-37.

Ounnar F., and Pujo, P. (2005). Evaluating suppliers within a self-organized logistical network The International Journal of Logistics Management, 16(1), 159-172.

Pitchipoo, P., P. Venkumar, and Rajakarunakaran, S. (2015). Grey decision model for supplier evaluation and selection in process industry: a comparative perspective, International Journal of Advanced Manufacturing Technology, 76 (9-12), 2059-2069.

Pramanik, D., A. Haldar, S. C. Mondal, S. K. Naskar, and Ray, A. (2017). Resilient supplier selection using AHPTOPSIS-QFD under a fuzzy environment, International Journal of Management Science and Engineering Management, 12(1), 45-54.

Safa, M., A. Shahi, C. T. Haas, and Hipel, K. W. (2014). Supplier selection process in an integrated construction materials management model, Automation in Construction, 48, 64-73.

Sarı, T. and Timor, M. (2016). Integrated supplier selection model using ANP, taguchi loss and promethee methods, Journal of Applied Quantitative Methods, 11(1), 19-34.

Sarkis, J., and Talluri, S. (2002). A model for strategic supplier selection, The Journal of Supply Chain Management, 2002(Winter), pp. 18-28.

Shahroudi, K., and Rouydel, H. (2012). Using a multi-criteria decision making approach (ANP-TOPSIS) to evaluate suppliers in Iran's auto industry, International Journal of Applied Operational Research, 2(2), 37 48 .

Shyur, H. J., and Shih, H. S. (2006). A hybrid MCDM model for strategic vendor selection, Mathematical and Computer Modelling, 44(7-8), 749-761.

Supçiller, A. A., and Çapraz, O. (2011). AHP-TOPSIS yöntemine dayalı tedarikçi seçimi uygulaması, Ekonometri ve İstatistik Dergisi, 13, 1-22. [in Turkish]

ŞTP. (2015). Şirket Tedarik Prosedürü (Company’s Procurement Procedure). İstanbul, Turkey: Company,. [in Turkish]

Tseng, Y. J., and Lin, Y. H. (2005). A model for supplier selection and tasks assignment, The Journal of American Academy of Business, 2, 197-207.

TWB. (2016). World Development Report: Digital Dividends, A report commissioned by The World Bank (TWB). Washington DC: TWB, 
Vahdani, B., S. Behzadi, and Mousavi, S. M. (2015). Artificial intelligence model based on LS-SVM for thirdparty logistics provider selection, International Journal of Industrial Mathematics, 7(4), 301-311.

Wu, M., and Liu, Z. (2011). The supplier selection application based on two methods: VIKOR algorithm with entropy method and fuzzy TOPSIS with vague sets method, International Journal of Management Science, 6(2), 109-115.

Wu, W.Y., B. M. Sukoco, C. Y. Li, and Chen, S. H. (2009). An integrated multi-objective decision-making process for supplier selection with bundling problem, Expert Systems with Applications, 36(2), 2327-2337.

Wu, M. Y. and Weng, Y. C.. (2010). A study of supplier selection factors for high-tech industries in the supply chain, Total Quality Management \& Business Excellence, 21(4), 391-413.

Yıldız, A. and Yayla, A. Y. (2017). Application of fuzzy TOPSIS and generalized choquet integral methods to select the best supplier, Decision Science Letters, 6(2), 137-150.

Zeydan, M., C. Colpan, and Cobanoglu C. (2011). A Combined methodology for supplier selection and performance evaluation, Expert Systems with Applications, 38(3), 2741-2751. 